\title{
Control of single phase grid connected transformerless PV inverter system
} Tek fazlı şebeke bağlantılı transformatörsüz PV evirici sistem kontrolü

\author{
Ahmet YÜKSEL ${ }^{1}$ iD , Emre ÖZKOP2* ${ }^{*}$ \\ 1,2Department of Electrical and Electronics Engineering, Engineering Faculty, Karadeniz Technical University, Trabzon, Turkey. \\ ahmetyuksel@ktu.edu.tr, eozkop@ktu.edu.tr
}

Received/Geliș Tarihi: 28.07.2017, Accepted/Kabul Tarihi: 29.06.2018

* Corresponding author/Yazışılan Yazar

doi: $10.5505 /$ pajes.2018.93275 Research Article/Araștırma Makalesi

\begin{abstract}
This paper presents the simulation performance of control of a gridconnected photovoltaic maximum power point tracking system with highly efficient and reliable inverter concept transformerless inverter. Perturb and Observe technique based on variation of power and voltage is used to extract maximum power from photovoltaic power system. A $d c-d c$ boost converter is applied with the technique by changing duty ratio of the PWM signal of the converter switch. A single-phase highly efficient and reliable inverter concept transformerless inverter provides a power flow into grid. The control of the inverter is based on the grid voltage and current and also dc-dc boost converter output voltage values. The system performance is evaluated in terms of PV module and $d c$-dc boost converter output voltages and currents, grid current and voltage, leakage current, active and reactive powers and power efficiency characteristics. The simulation results show $97.96 \%$ maximum efficiency, 96.84\% European efficiency and 97.60\% Californian efficiency with $20 \mathrm{kHz}$ switching frequency for the HERIC inverter on the proposed system.
\end{abstract}

Keywords: MPPT, Transformerless inverter, PV, Grid-Connected

\begin{abstract}
Öz
Bu çalışma, çok verimli ve güvenli evirici konseptli transformatörsüz eviricili șebeke bağlantılı fotovoltaik maksimum güç noktası takip sisteminin kontrolünün benzetim performansını sunmaktadır. Güç ve gerilimin değișimini temel alan dürt ve gözlemle tekniği, fotovoltaik birim sisteminden maksimum güç elde etmek için kullanılmaktadır. DA-DA yükselten çevirici bu teknik ile çevirici anahtarına ait PWM sinyalinin doluluk oranı değiştirilerek uygulanmaktadır. Tek fazlı çok verimli ve güvenli evirici konseptli transformatörsüz evirici, şebekeye güç akışını sağlamaktadır. Evirici kontrolü, şebeke gerilimi ve akımı ve ayrıca DA-DA yükselten çevirici çıkış gerilim değerlerine dayanmaktadır. Sistem performansı, PV modül ve DA-DA yükselten çevirici çıkış gerilim ve akımları, şebeke akımı ve gerilimi, kaçak akım, aktif ve reaktif güçler ve güç verim karakteristiği yönünden değerlendirilmektedir. Önerilen sistemde benzetim sonuçları HERIC evirici için maksimum verimini \%97.96, Avrupal verimini \%96.84 ve Kaliforniyall verimini \%97.60 olarak $20 \mathrm{kHz}$ anahtarlama frekansinda göstermektedir.
\end{abstract}

Anahtar kelimeler: MPPT, Transformatörsüz evirici, PV, Şebeke bağlantılı

\section{Introduction}

The photovoltaic (PV) energy sector has been growing gradually. Each year, new PV application examples come up and this situation arouses uncharacteristically interest on consumers and producers. Each of studies and works on PV systems makes positive effects on the PV costs. While available and expected information on the costs shows that the cost of PV modules has decreased, penetration of the energy system based on the PV has increased [1]. Solar PV market has grown and global PV capacity has reached almost 300 GW. During 2016, the installation of more than thirty thousand solar panels every hour was realized that can be given as an example of the growth momentum [2].

While stand-alone PV power generation system applications were more widespread in the past, grid-connected PV applications are more preferred to meet rapidly rising electricity demand nowadays. Both centralized and decentralized (residential, commercial and rooftop systems) grid-connected applications have risen more quickly since 2006 [2]. In residential PV power generation applications, a power electronic system is used to convert PV dc power into ac power and transfer to the utility grid. The power electronic system can consist of dc-dc converter, dc/ac inverter and related controller for the converter and inverter depending on the system design. dc/ac inverter topologies can be designed both with and without using transformer. In recent years, developed PV inverter topologies are based on transformerless structures since the transformer usage increases cost and size and also reduces efficiency and makes the system too heavy and big [1]. On the other hand, transformerless structure may cause leakage current to flow throughout inverter circuit and that can reveal safety problems [1].

Many transformerless topologies such as H5, H6, Highly Efficient and Reliable Inverter Concept (HERIC), H-Bridge Zero-Voltage state Rectifier (HBZVR), Full-Bridge inverter with DC ByPass (FB-DCBP), Half-Bridge Neutral Point Clamped (HB-NPC) have been used in literature and these topologies have advantages and disadvantages, relative to each other [3]-[5]. The pros and cons of the topologies can be defined by performances comparison in terms of efficiency (conversion, European, Californian, and etc.), common-mode (CM) voltage, leakage current, power quality, low-voltage ride-through (LVRT) capability, reactive power injection and current stresses [6]-[8]. HERIC inverter, which is one of the transformerless inverter topologies, is assumed as one of the most efficient, reliable, and approximately leakage free inverters with the PV-grid connected systems [1],[9].

The dc-dc converter is one of important parts of PV generation system and variable dc-dc power converter topologies are used to extract a maximum power from PV energy systems in literature. Generally, a power converter is controlled with a maximum power point tracking (MPPT) technique to realize the purpose. There are variable combination of dc-dc converters and MPPT techniques. For example, boost, buckboost, SEPIC (single-ended primary inductance converter), 
boost-flyback, interleaved-boost, boost-cuk can be given as dc$\mathrm{dc}$ converter topologies used with MPPT techniques [10]-[15]. Due to non-linear voltage-current characteristics of the PV modules and impacts of weather conditions on PV power generation, necessity of tracking of maximum power point of the PV arises to extract maximum power [16]. There are various MPPT algorithms in literature and some of them such as Perturb and Observe (P\&O), Incremental Conductance (INC), dp/di or $\mathrm{dp} / \mathrm{dv}$ and optimization based methods that stand out where each of them has pros and cons that should be reconsidered [17].

In this paper, a grid-connected PV MPPT system with transformerless HERIC inverter is designed, controlled and simulated. The system consists of PV unit, dc-dc boost converter, HERIC inverter and utility grid. To extract maximum power from the PV unit, dc-dc boost converter is applied with P\&O MPPT algorithm. To inject current into the grid, the HERIC inverter is considered with a cascaded control of the dc voltage through the ac current strategy. This paper presents a series connected PV modules, dc-dc boost converter operated at low switching frequency and HERIC inverter operated at high switching frequency and electric power grid operated at grid frequency with CLC, LC, LCL filters structure, respectively. This paper shows that a PV MPPT system based dc-dc boost converter for feeding HERIC inverter without the need for high-frequency switching and complex control algorithm. The proposed grid-connected transformerless PV inverter system is constructed for simple structure, non-complex control algorithms, less computation time for hardware and minor sensitivity to switching frequency level.

\section{System design}

An architecture of grid-connected PV MPPT system with transformerless inverter is shown in Figure 1. PV modules, CLC filter, dc-dc boost converter, LC filter, transformerless inverter, LCL filter and grid are main parts of the system. The output of PV modules is controlled to extract maximum power by the means of MPPT algorithm based on perturbation \& observe structure. An LC filter is inserted between the dc-dc boost converter and $\mathrm{dc} / \mathrm{ac}$ transformerless inverter not only to reduce the voltage ripple but also to suppress the current harmonics and effects of switching frequency differences and limit the electromagnetic interference (EMI). And then, dc voltage is converted into ac voltage waveform by the transformerless inverter and injected to the grid through the LCL filter.

\subsection{Maximum power point tracking algorithm}

In this paper, the P\&O technique is used as an MPPT algorithm. The voltage of PV system is perturbed by changing the pulse width modulation (PWM) duty ratio switch in the dc-dc power converter at regular intervals to define the direction change for maximizing power. And then, a power comparison between value at present perturbation cycle and value at previous perturbation cycle is done. Consequentially, to track the maximum power point, power and voltage values are employed in this technique. The voltage and current measurement are applied to calculate PV power.

$$
P_{P V}(k)=V_{P V}(k) \times I_{P V}(k)
$$

where $k$ is an iteration number and $P_{P V}(k), V_{P V}(k)$ and $I_{P V}(k)$ are power, voltage and current values of PV system output, respectively.

The variation on voltage and power defined in Equations (2) and (3) determines the instantaneous operation point and decides action requirement type.

$$
\begin{aligned}
& \Delta V_{P V}=V_{P V}(k)-V_{P V}(k-1) \\
& \Delta P_{P V}=P_{P V}(k)-P_{P V}(k-1)
\end{aligned}
$$

where $P_{P V}(k-1)$ and $V_{P V}(k-1)$ are the previous PV system power and voltage, and $\Delta V_{P V}$ and $\Delta P_{P V}$ are the change in PV system voltage and $P V$ system power, respectively.

The possible scenarios related to the variations on power and voltage can be tabulated as given in Table 1 . The possible scenarios (Table 1) can be illustrated as shown in Figure 2.

Table 1: The possible scenarios for the P\&O technique.

\begin{tabular}{ccccc}
\hline \multicolumn{2}{c}{ STATUS } & ACTION & \multicolumn{2}{c}{ SCENARIO } \\
\hline$\Delta P_{P V}$ & $\Delta V_{P V}$ & $V_{\text {ref }}(k)$ & Movement & Step \\
Positive & Positive & Increase & C-->A & V \\
Positive & Negative & Decrease & A-->C & II \\
Negative & Positive & Decrease & B-->D & III \\
Negative & Negative & Increase & D-->C & I \\
Zero & - & Constant & & \\
\hline
\end{tabular}

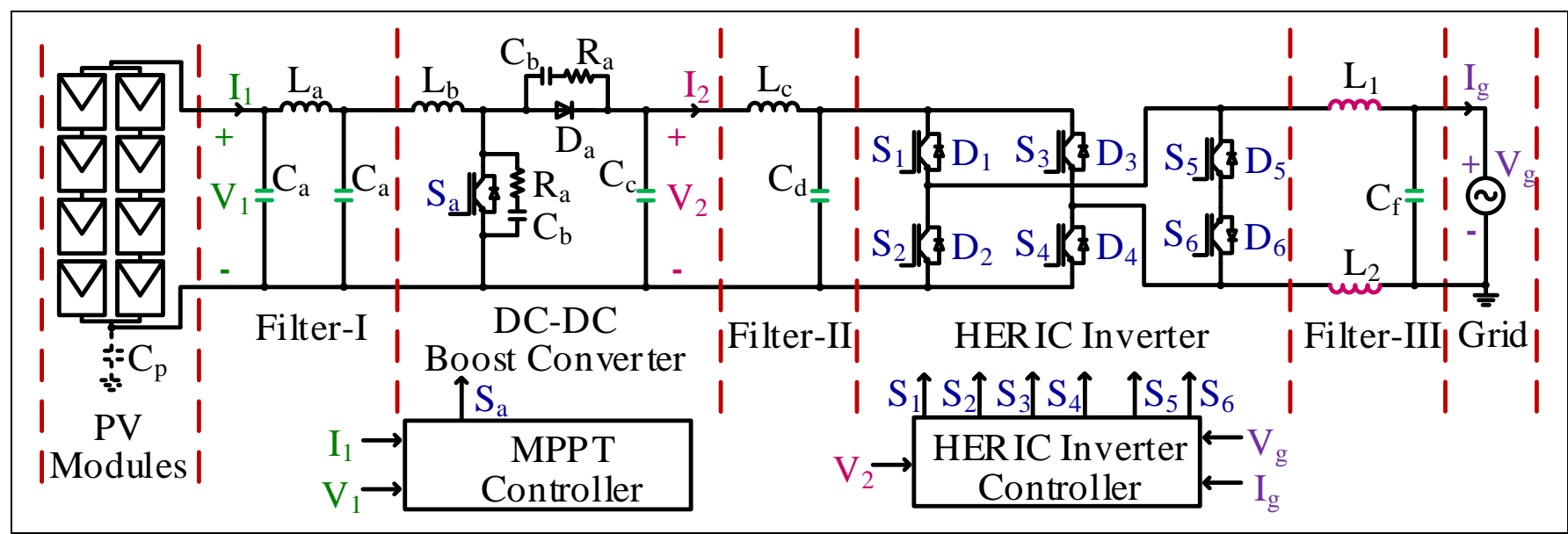

Figure 1: Schematic for the simulation setup of the grid-connected PV MPPT system with the transformerless inverter. 


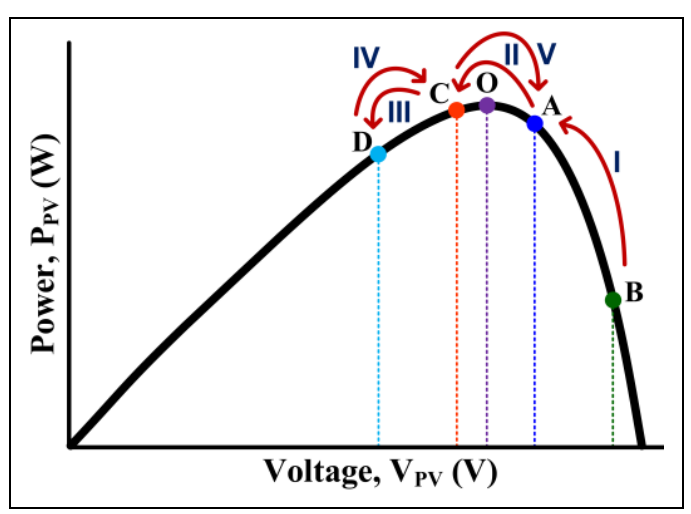

Figure 2: Behavior of P\&O MPPT algorithm with reference voltage perturbation $\left(V_{\text {ref }}(k)\right)$.

It is assumed that solar irradiance and temperature are constant during the PV system operation, initial reference point is point $\mathrm{A}$, and also the initial perturbation direction is to increase the reference voltage. The operating point moves to $B$ due to the initial perturbation direction. After that, the PV system output voltage and current are measured and the PV system output power is calculated. Since the power is decreased and voltage is increased at point $B$ (compared with point $\mathrm{A}$ ), the $\mathrm{P} \& \mathrm{O}$ algorithm reverses the perturbation direction by decreasing the reference voltage $\left(V_{r e f}(k)\right)$ and the operation point moves to point A (Step-I). Thereafter the operating point moves to point $\mathrm{C}$ due to the increase in power and decrease in voltage (Step-II). As long as the power at point $\mathrm{C}$ is higher than that at point $A$ and the voltage at point $C$ is lower than that at point $\mathrm{A}$, the $\mathrm{P} \& \mathrm{O}$ algorithm continues to decrease the reference voltage $\left(V_{r e f}(k)\right)$ and the operation point moves to point D (Step-III). At point D, the power and voltage values are smaller than the values at point $\mathrm{C}$ so that the $\mathrm{P} \& 0$ algorithm reverses the perturbation direction by increasing the reference voltage $\left(V_{\text {ref }}(k)\right)$ and the operation point moves to point C (Step-IV). Consequently, the $\mathrm{P} \& 0$ algorithm keeps increasing the voltage $\left(V_{\text {ref }}(k)\right)$ and the operation point moves to point A (Step-V) since the power and voltage at point $C$ are higher than that at point $\mathrm{D}$ and the sequence is repeated.

The action on voltage $\left(V_{r e f}(k)\right)$ is realized by changing the duty cycle of the PWM signal of switch of dc-dc boost converter in this study. The operation principles of the P\&O technique are illustrated as a flowchart diagram as shown in Figure 3.

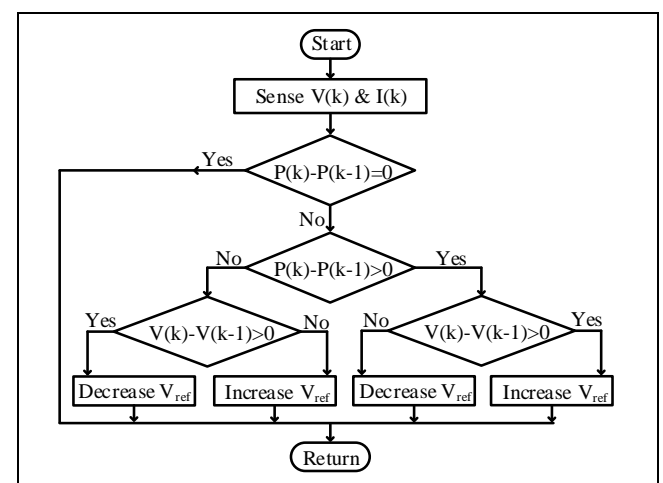

Figure 3: Flowchart of $\mathrm{P} \& 0$ technique structure.

In the P\&O-MPPT algorithm (Figure 3), the PV system output voltage $\left(V_{P V}(k)\right)$ and current $\left(I_{P V}(k)\right)$ are measured, allowing the calculation of the PV system output power $\left(P_{P V}(k)\right)$ and thereafter $P_{P V}(k)$ and $V_{P V}(k)$ are compared with their previously calculated and measured respective values $\left(P_{P V}(k-1)\right.$ and $\left.V_{P V}(k-1)\right)$. When both the change in PV system power $\left(\Delta P_{P V}\right)$ and change in PV system voltage $\left(\Delta V_{P V}\right)$ are positive or negative, the controller increases the voltage reference $V_{\text {ref }}(k)$. On the other hand, if the change in PV system power or change in PV system voltage is negative, the voltage reference $V_{\text {ref }}(k)$ is decreased. Thus, the MPPT algorithm operates by incrementing or decrementing $V_{r e f}(k)$ to extract the maximum power from the PV array.

\subsection{DC-DC power converter}

In this paper, a dc-dc boost converter topology is used with MPPT algorithm since it has simple structure, low cost and widespread usage for MPPT applications [18],[19]. The boost converter is a bridge and controlled interface device between the PV modules and the inverter and used to extract maximum power from the PV modules by changing duty cycle of the power switch $\left(\mathrm{S}_{\mathrm{a}}\right)$. The boost converter working modes are shown in Figure 4.

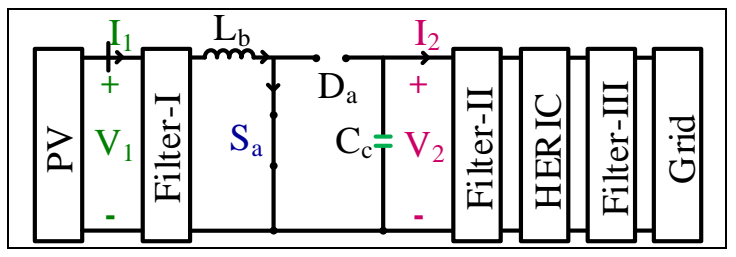

(a): Mode-I $\left(\mathrm{S}_{\mathrm{a}}: \mathrm{ON}\right)$.

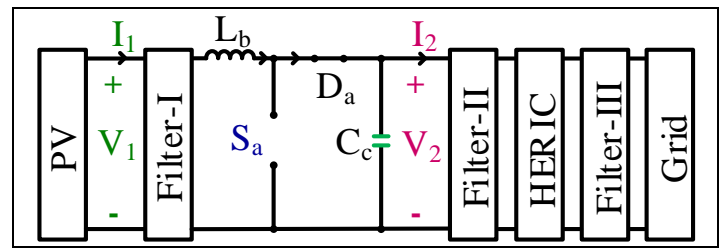

(b): Mode-II $\left(\mathrm{S}_{\mathrm{a}}\right.$ : OFF).

Figure 4: The boost converter working modes.

In Mode-I (shown in Figure $4(a)$ ), the diode $\left(D_{a}\right)$ is reverse biased as the PV system output current flows through the inductance $\left(L_{a}\right)$ and the current grows linearly. In this way, the $\mathrm{PV}$ modules power is stored in the inductance while the capacitor $\left(\mathrm{C}_{\mathrm{c}}\right)$ injects the energy into the HERIC inverter.

In Mode-II (shown in Figure 4(b)), the input side (PV modules and Filter-I parts) is connected to output side (Filter-II, HERIC inverter, Filter-III and grid parts) through the inductance $\left(\mathrm{L}_{\mathrm{a}}\right)$ and the diode $\left(D_{a}\right)$ since the power switch $\left(S_{a}\right)$ is OFF-state.

The dynamic model of the converter in a state-space can be defined with neglecting of the effect of Filter-I and assuming that load (R) is connected to the converter output as follows:

$$
\begin{gathered}
\frac{d i_{1}}{d t}=\frac{V_{1}-V_{2}}{L_{a}}+\frac{V_{2}}{L_{a}} \cdot u \\
\frac{d V_{2}}{d t}=\left(-\frac{V_{2}}{R C_{c}}+\frac{i_{1}}{C_{c}}\right)-\frac{i_{1}}{C_{c}} \cdot u
\end{gathered}
$$

where $u$ is the control input, which defines the switch position; while the switch is ON-state, $u$ is set to zero (0), and $u$ is set to one (1), as the switch is OFF-state

Since information about the boost converter operation can be found in any power electronics book [26] and paper [27], no more details are given here. 


\subsection{HERIC inverter}

HERIC inverter topology is based on six switches $\left(S_{1}-S_{6}\right)$ which of four are switched at high frequency and two are switched at grid frequency. The operation statements and sinusoidal pulse-with modulation (SPWM) scheme for the HERIC inverter are illustrated in Figures 5 and 6, respectively.

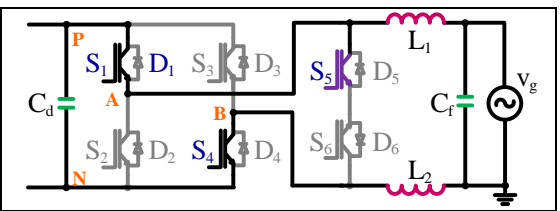

(a) Stage 1

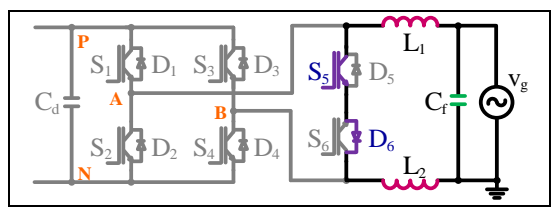

(b) Stage 2

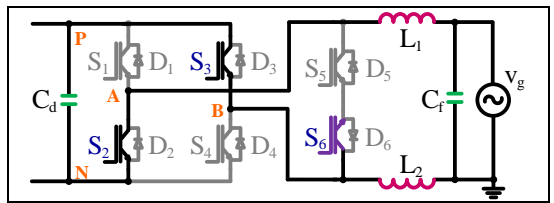

(c) Stage 3

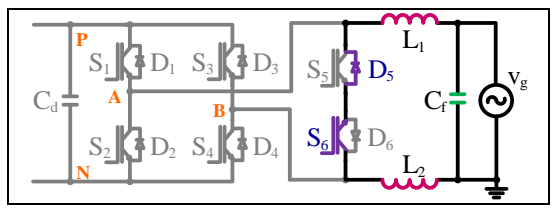

(d) Stage 4

Figure 5: The operation stages of the HERIC inverter.

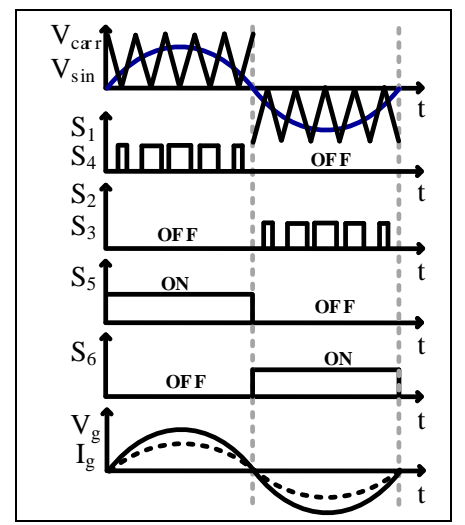

Figure 6: Switching pattern for the HERIC inverter.

It is assumed that the negative terminal " $\mathrm{N}$ " of PV modules is a reference point, the bridge leg midpoints " $\mathrm{A}$ " and " $\mathrm{B}$ " are output terminals and the voltage difference between positive terminal "P" and negative terminal " $\mathrm{N}$ " of PV modules is $v_{P N}$. The generated common-mode voltage $\left(v_{C M}\right)$ and differential-mode voltage $\left(v_{D M}\right)$ are related to voltage of terminal " $\mathrm{A}$ " to " $\mathrm{N}$ " $\left(v_{A N}\right)$ and voltage of terminal " $\mathrm{B}$ " to " $\mathrm{N}$ " $\left(v_{B N}\right)$, as given in the following:

$$
v_{C M}=\frac{v_{A N}+v_{B N}}{2}
$$

$$
v_{D M}=v_{A N}-v_{B N}
$$

The control loop generates a modulation signal $\left(v_{\sin }\right)$ and it is locked to the grid voltage $\left(v_{g}\right)$ in phase and frequency. The modulation signal $\left(v_{\text {sin }}\right)$ and the carrier signal $\left(v_{\text {carr }}\right)$ are compared to set the gate signals for the switches $\left(S_{1}-S_{6}\right)$. There are four main operating stages in a grid period time.

In stage 1 (shown in Figure 5(a)), $S_{1}, S_{4}$ and $S_{5}$ are all in the ON-state while $S_{2}, S_{3}$ and $S_{6}$ are all in the OFF-state. The current flows through $S_{1}$ and $S_{4}$ from the PV side to utility grid. The generated common-mode voltage $\left(v_{C M}\right)$ and differential-mode voltage $\left(v_{D M}\right)$ at this stage are

$$
v_{A N}=v_{P N} ; \quad v_{B N}=0: \quad v_{C M}=\frac{v_{P N}}{2} \quad \text { and } \quad v_{D M}=v_{P N}
$$

In stage 2 (shown in Figure 5(b)), $S_{1}-S_{4}$ and $S_{6}$ are all in the OFF-state and the grid current freewheels through $S_{5}$ and anti-parallel diode $\left(D_{6}\right)$ of switch $S_{6}$. During this stage, the PV side is disconnected from the electrical utility grid as shown in Figure 5b. The common-mode and differential-mode voltages are

$$
v_{A N}=0 ; \quad v_{B N}=0: \quad v_{C M}=0 \quad \text { and } \quad v_{D M}=0
$$

In stage 3 (shown in Figure 5(c)), $S_{2}, S_{3}$ and $S_{6}$ are all in the ONstate while $S_{1}, S_{4}$ and $S_{5}$ are all in the OFF-state. The current flows through $S_{2}$ and $S_{3}$ from the PV side to utility grid. The mode voltages are

$v_{A N}=0 ; \quad v_{B N}=v_{P N}: \quad v_{C M}=\frac{v_{P N}}{2} \quad$ and $\quad v_{D M}=-v_{P N}$

In stage 4 (shown in Figure $5(\mathrm{~d})$ ), $S_{1}-S_{4}$ and $S_{6}$ are all in the OFF-state and the grid current freewheels through $S_{6}$ and anti-parallel diode $\left(D_{5}\right)$ of switch $S_{5}$. In this stage, the PV side is disconnected from the electrical utility grid as shown in Figure $5 \mathrm{~d}$. The mode voltages are

$$
v_{A N}=0 ; \quad v_{B N}=0: \quad v_{C M}=0 \quad \text { and } \quad v_{D M}=0
$$

The HERIC inverter topology has some advantages such as lower core losses, higher efficiency due to no reactive power exchange between filters during zero voltage and to lower frequency switching in one leg and very low leakage current and EMI.

The topology consists of full-bridge side and ac decoupling parts. As a full-bridge side with unipolar SPWM causes a large leakage current, ac decoupling part, which provides galvanic isolation, reduces the leakage current based on high frequency pulsation [3],[20] and there are different types of decoupling topologies in the literature [21],[22]. The leakage current limit is defined by different standard associations. For example, in the VDE-0126-1-1 standard, a maximum leakage current value is equal to $300 \mathrm{~mA}$ and if the current exceeds this limit, the system has to work in islanding mode in 0.3 second [5],[7].

\subsubsection{Controller for HERIC inverter}

The HERIC Inverter control system is based on cascaded control of the dc voltage through the ac current strategy. The general control structure of HERIC inverter is shown in Figure 7. This cascade control strategy consists of voltage and current regulation sides. As the voltage regulation side determines the required reference current for current regulation side, the current regulation side determines the required reference voltage for the HERIC inverter. 


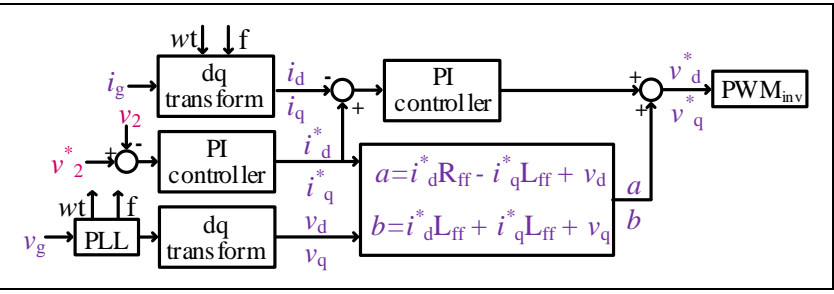

Figure 7: General control structure of HERIC inverter.

In grid-connected application, synchronization standards have to be provided by the control mechanism. The injected current quality depends on the grid synchronization. The grid voltage is used for synchronization. The grid voltage information is extracted by using phase-locked loop (PLL) technique.

\subsection{Efficiency and power quality}

An inverter performance can be revealed by numerical efficiency indicators such as conversion efficiency, European efficiency, Californian efficiency, etc [7],[23]. The conversion efficiency $\left(\eta_{\text {Con }}\right)$ is defined by rate of alternating current power at output of the inverter and direct current power at input of the inverter as given below:

$$
\eta_{\text {Con }}=\frac{P_{A C}}{P_{D C}}
$$

The conversion efficiency can be named as the peak efficiency and deceptive to show inverter performance for different part of load region. Therefore, the European efficiency $\left(\eta_{E u}\right)$ is described to reveal a relationship between partial load conditions and inverter performance more reliably and realistically as given below [1],[24]:

$$
\begin{gathered}
\eta_{E u}=0.03 \cdot \eta_{5 \%}+0.06 \cdot \eta_{10 \%}+0.13 \cdot \eta_{20 \%}+0.1 \cdot \eta_{30 \%} \\
+0.48 \cdot \eta_{50 \%}+0.2 \cdot \eta_{100 \%}
\end{gathered}
$$

where $\eta_{x \%}$ : conversion efficiency at a respective part-load of $x \%$

Another efficiency indicator is Californian efficiency and it is calculated as given equation below [3]:

$$
\begin{array}{r}
\eta_{C a}=0.04 \cdot \eta_{10 \%}+0.05 \cdot \eta_{20 \%}+0.12 \cdot \eta_{30 \%}+0.21 \\
\cdot \eta_{50 \%}+0.53 \cdot \eta_{75 \%}+0.05 \cdot \eta_{100 \%}
\end{array}
$$

An inverter power quality can be expressed by the Total Harmonic Distortion (THD) value of the inverter outputs (current and voltage). For instance, the grid current THD limit recommended in the IEEE 1547-2003 standard is less than 5\% [7]

\section{Simulation}

The grid-connected PV MPPT system with HERIC transformerless inverter is simulated by Matlab/Simulink

\begin{tabular}{|c|c|c|c|}
\hline \multicolumn{2}{|c|}{ Photovoltaic system } & \multicolumn{2}{|r|}{ dc-dc power converter } \\
\hline$\overline{V_{\text {oc }}}$ & & $\mathrm{L}_{\mathrm{b}}$ & $2.55 \mathrm{uH}$ \\
\hline$I_{s c}$ & & $\mathrm{R}_{\mathrm{a}}$ & $33 \mathrm{Ohm}$ \\
\hline $\mathrm{N}_{\text {series }}$ & & $\mathrm{C}_{\mathrm{b}}$ & $300 \mathrm{pF}$ \\
\hline$N_{\text {parallel }}$ & & $\mathrm{C}_{\mathrm{c}}$ & $1 \mathrm{mF}$ \\
\hline $\mathrm{C}_{\mathrm{p}}$ & $\mathrm{pF}$ & $\mathrm{f}_{\mathrm{s}}$ & $1 \mathrm{kHz}$ \\
\hline \multicolumn{2}{|c|}{ Filter-I } & \multicolumn{2}{|r|}{ Filter-II } \\
\hline $\mathrm{L}_{\mathrm{a}}$ & & \multirow{2}{*}{\multicolumn{2}{|c|}{$\begin{array}{l}0.338 \mathrm{uH} \\
10 \mathrm{mF}\end{array}$}} \\
\hline \multicolumn{2}{|c|}{$33 \mathrm{uF}$} & & \\
\hline \multicolumn{2}{|c|}{ Filter -III } & \multicolumn{2}{|r|}{ Grid } \\
\hline$\overline{\mathrm{L}_{1}}$ & $1.8 \mathrm{mH}$ & $\mathrm{f}$ & $50 \mathrm{~Hz}$ \\
\hline $\mathrm{L}_{2}$ & $1.8 \mathrm{mH}$ & $\mathrm{V}$ & $240 \mathrm{~V}$ \\
\hline \multirow[t]{2}{*}{$\mathrm{C}_{\mathrm{f}}$} & $2 \mathrm{nF}$ & \multicolumn{2}{|r|}{ HERIC Controller } \\
\hline & HERIC & & Rff $\quad 0.002 \mathrm{Ohm}$ \\
\hline $\mathrm{f}_{\mathrm{s}}$ & $20 \mathrm{kHz}$ & & $\begin{array}{ll}\text { Lff } & 0.2 \mathrm{H}\end{array}$ \\
\hline \multicolumn{2}{|c|}{ IGBT } & \multicolumn{2}{|r|}{ Voltage PI controller } \\
\hline Ron & $1 \mathrm{mOhm}$ & & $\begin{array}{ll}\mathrm{K}_{\mathrm{P}} & 12\end{array}$ \\
\hline Lon & $0 \mathrm{mH}$ & & 200 \\
\hline $\mathrm{Vf}$ & $2.5 \mathrm{~V}$ & \multicolumn{2}{|r|}{ Current PI controller } \\
\hline \multicolumn{2}{|c|}{ Diode } & & $\begin{array}{ll}\mathrm{K}_{\mathrm{P}} & 0.15\end{array}$ \\
\hline Ron & $1 \mathrm{mOhm}$ & & 6.6 \\
\hline Lon & $0 \mathrm{mH}$ & & \\
\hline $\mathrm{Vf}$ & $1.6 \mathrm{~V}$ & & \\
\hline
\end{tabular}
environment. Figure 8 demonstrates the Simulink block diagram of proposed system. The system simulation parameters are given in Table 2 .

Table 2: The system simulation parameters.

The system simulation is realized for different input PV power values and conversion efficiency ( $\left.\eta_{\text {Con }}\right)$ of the HERIC inverter is determined and tabulated as given Table 3. European and Californian efficiency values are calculated by using Equations (12) and (13), respectively. The detailed calculation process and analysis of device losses in transformerless inverters are given in reference [25].

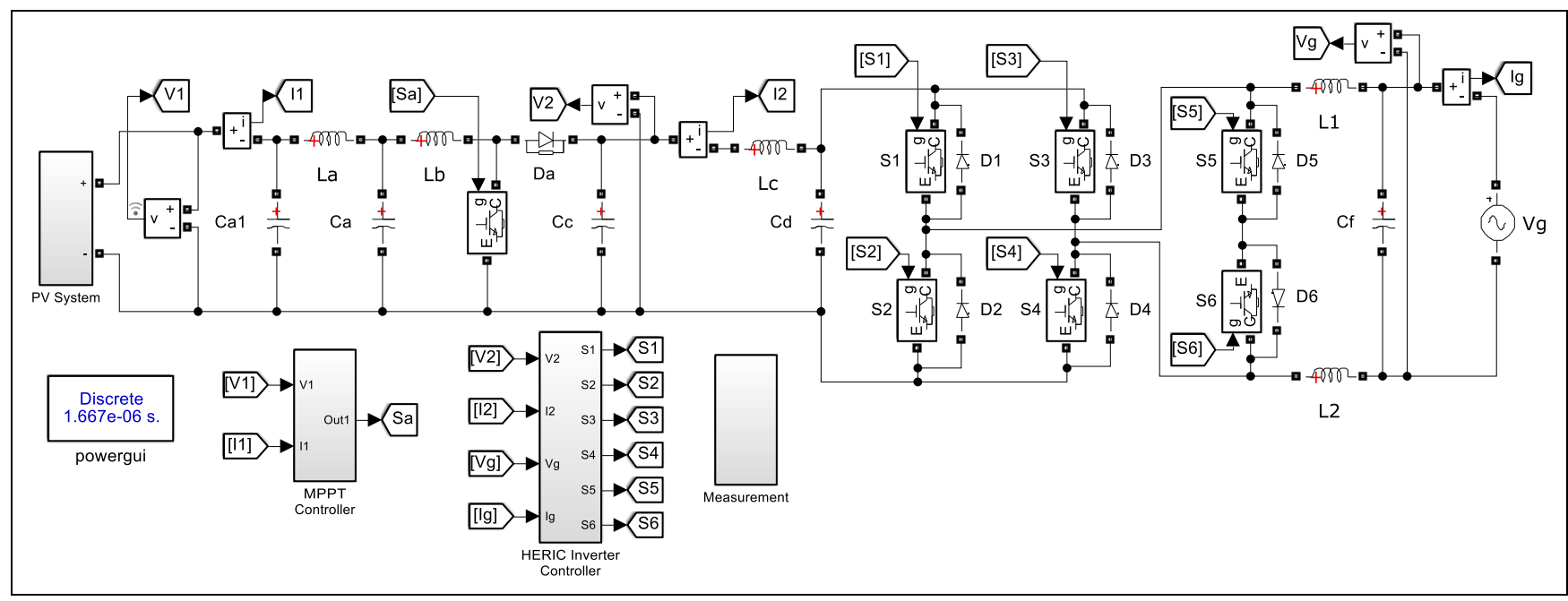

Figure 8: MATLAB/Simulink block diagram of proposed system. 
Table 3: Efficiency for the HERIC inverter in the power system.

\begin{tabular}{ccccccc}
\hline $\boldsymbol{\eta}_{\mathbf{5} \%}$ & $\boldsymbol{\eta}_{\mathbf{1 0} \%}$ & $\boldsymbol{\eta}_{\mathbf{2 0} \%}$ & $\boldsymbol{\eta}_{\mathbf{3 0} \%}$ & $\boldsymbol{\eta}_{\mathbf{5 0} \%}$ & $\boldsymbol{\eta}_{\mathbf{7 5} \%}$ & $\boldsymbol{\eta}_{\mathbf{1 0 0} \%}$ \\
\hline 79.46 & 94.79 & 96.66 & 97.21 & 97.70 & 97.92 & 97.96 \\
$\boldsymbol{\eta}_{\boldsymbol{E u}}$ & $\boldsymbol{\eta}_{\boldsymbol{C a}}$ & & & & & \\
96.84 & 97.60 & & & & & \\
\hline
\end{tabular}

Figures 9-14 show the digital simulation results of the grid-connected PV MPPT system with HERIC transformerless inverter grid voltage and current, dc-dc boost converter output voltage and current, PV output voltage and current, HERIC inverter output power and voltage and the earth leakage current for one case.

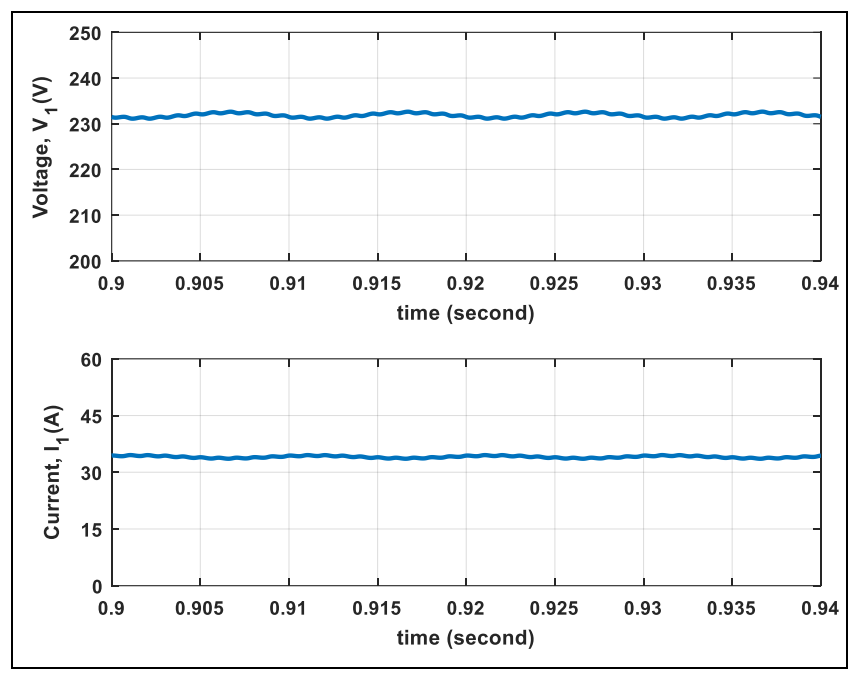

Figure 9: PV output voltage and current.

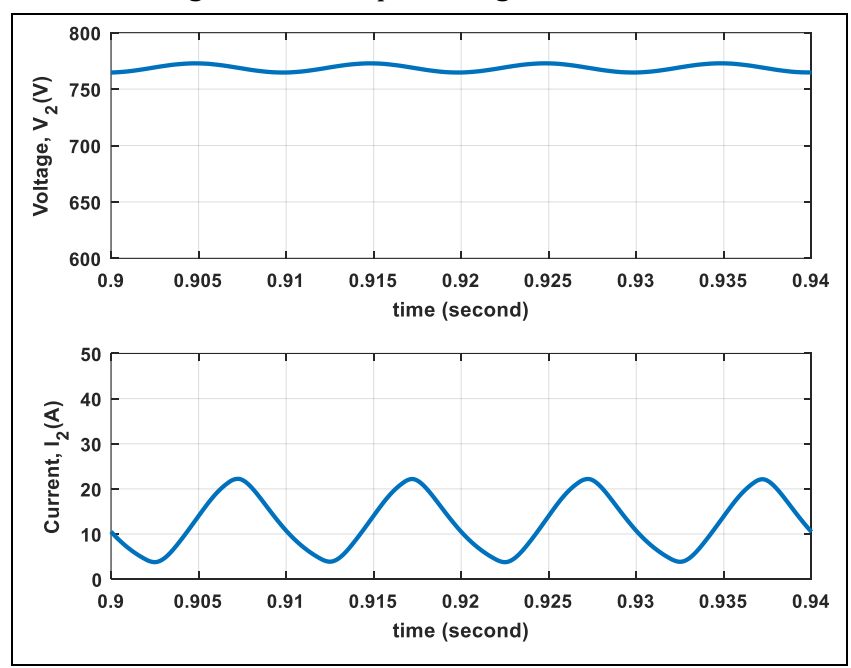

Figure 10: Boost converter output voltage and current.

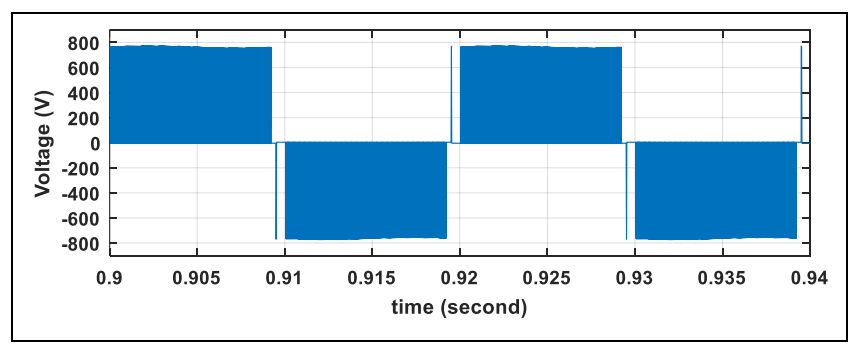

Figure 11: HERIC inverter output voltage.

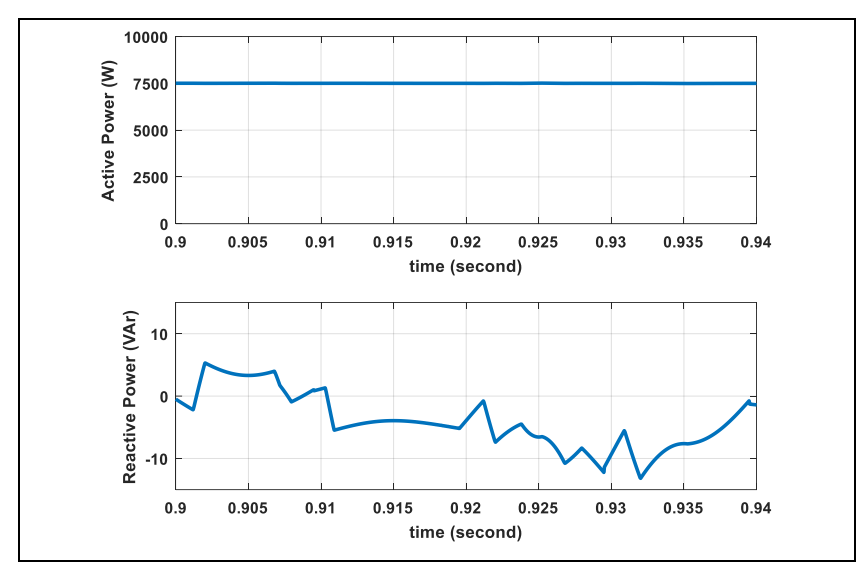

Figure 12: HERIC inverter output power.

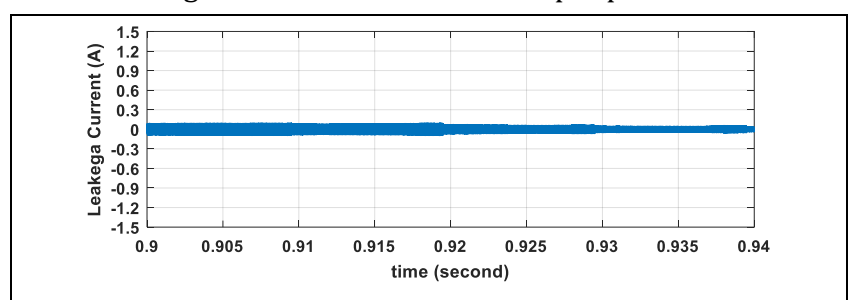

Figure 13: Earth leakage current.

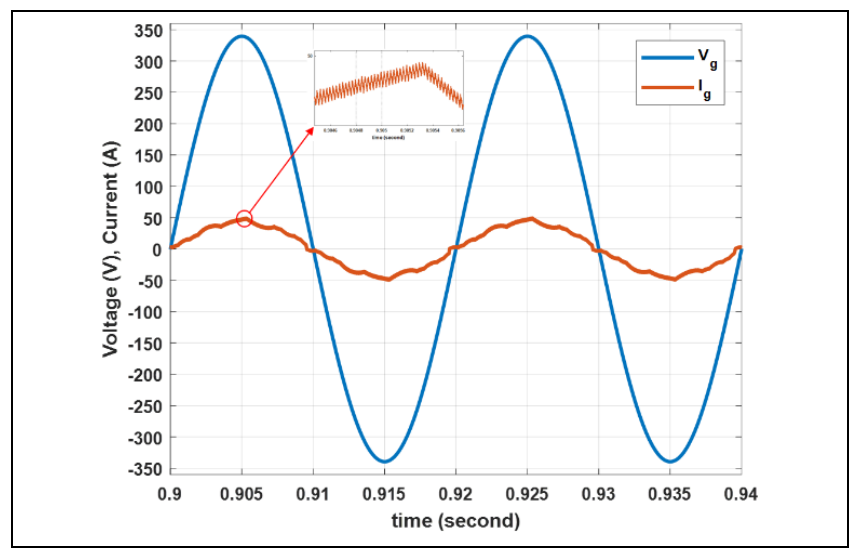

Figure 14: Grid voltage and current.

Figure 9 shows that the photovoltaic output current and voltage values are constant to insure true maximum power point tracking operation. The P\&O MPPT algorithm based on PV power and voltage variations, the boost converter helps to maximize power extraction so that the boost output voltage does not change as the output voltage as shown in Figure 10. The HERIC inverter output voltage waveform is three level and frequency is as same as the grid side as shown in Figure 11. In the system discussed in this paper, the main aim is to transfer dc power to the utility grid as ac power with as much as less injecting or absorbing reactive power. In the HERIC inverter output, as active power value is kept at maximum level, reactive power value is pushed into the zero level as shown in Figure 12. From Figure 13, we can see that the earth leakage current is less than the standards of German VDE -0126-1-1, [5]. As shown in Figure 14, the grid current ripple is small and synchronized with the grid voltage without any phase shifting. There are little glitches during the zero crossing due to AC decoupling circuit effects. The grid current is completely symmetrical during the positive and negative half cycle. FFT analysis of grid current is shown in Figure 15 and tabulated in Table 4. 


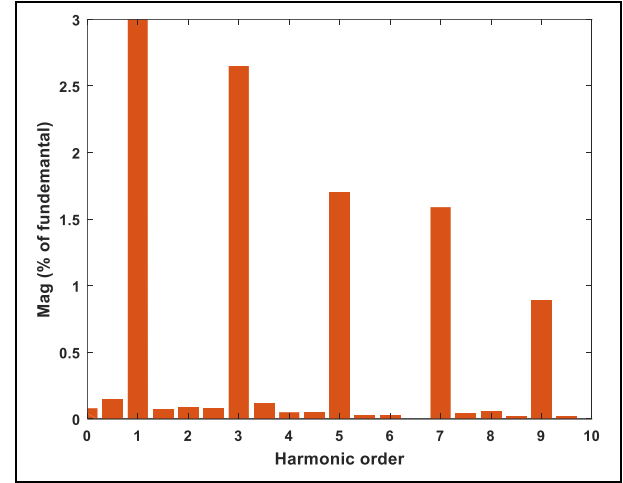

Figure 15: FFT analysis of current in the sample study system.

\section{Conclusion}

This study investigates the performance and characteristics of the grid-connected PV MPPT system via HERIC transformerless inverter. The dc-dc boost converter is used to manage the PV output and also P\&O MPPT algorithm is applied to control the $\mathrm{dc}$-dc boost converter for maximum power extraction. The boosted output voltage is fed to the HERIC inverter to inject current into the utility grid. The HERIC inverter efficiency is determined with the PV MPPT system for conversion, European and Californian efficiency perspectives. From the digital simulation results, it is shown that leakage current is below the standard limits, the current injected in to the utility grid is synchronized with grid and a reactive power level is minimized by the current regulation side of the HERIC inverter control system.

This paper attempts to enhance the PV MPPT system and transformerless PV inverter knowledge by simulating the system for different input power values.

Table 4: Current harmonics in the sample study system.

\begin{tabular}{|c|c|c|c|c|c|}
\hline & THD (\%) & $3^{\text {rd }}(\%)$ & $5^{\text {th }}(\%)$ & $7^{\text {th }}(\%)$ & $9^{\text {th }}(\%)$ \\
\hline The system & 4.39 & 2.65 & 1.70 & 1.59 & 0.89 \\
\hline IEEE 1547 [7] & $\leq 5.00$ & $\leq 4.00$ & $\leq 4.00$ & $\leq 4.00$ & $\leq 4.00$ \\
\hline
\end{tabular}

\section{Nomenclature \& Abbreviation}

\begin{tabular}{|c|c|}
\hline $\mathrm{AC}$ & Alternative current \\
\hline CM & Common-mode \\
\hline DC & Direct current \\
\hline EMI & Electromagnetic interference \\
\hline FB-DCBP & Full-bridge inverter with dc bypass \\
\hline FFT & Fast Fourier transform \\
\hline HB-NPC & Half-bridge neutral point clamped \\
\hline HBZVR & H-bridge zero-voltage state rectifier \\
\hline HERIC & Highly efficient and reliable inverter concept \\
\hline INC & Incremental conductance \\
\hline LVRT & Low-voltage ride-through \\
\hline MPPT & Maximum power point tracking \\
\hline PLL & Phase-locked loop \\
\hline $\mathrm{P} \& 0$ & Perturb and observe \\
\hline PV & Photovoltaic \\
\hline PWM & Pulse width modulation \\
\hline SPWM & Sinusoidal pulse-with modulation \\
\hline THD & Total Harmonic Distortion \\
\hline$f$ & Frequency \\
\hline$I_{P V}$ & PV system current \\
\hline$I_{g}$ & Grid current \\
\hline$I_{1}$ & PV output current \\
\hline$I_{2}$ & Boost converter output current \\
\hline$i_{d}$ & Direct current in $\mathrm{d}-\mathrm{q}$ frame \\
\hline$i_{q}$ & Quadrature current in $\mathrm{d}-\mathrm{q}$ frame \\
\hline$i_{d}^{*}$ & Direct current control signal in $\mathrm{d}-\mathrm{q}$ frame \\
\hline$i_{q}^{*}$ & Quadrature current control signal in $d-q$ frame \\
\hline$k$ & Iteration number \\
\hline$L_{f f}$ & Feedforward inductance \\
\hline
\end{tabular}

\begin{tabular}{|c|c|}
\hline$P_{A C}$ & Alternating current power \\
\hline$P_{D C}$ & Direct current power \\
\hline$P_{P V}$ & PV system power \\
\hline$R_{f f}$ & Feedforward resistance \\
\hline$S_{\mathrm{a}}$ & Switch in dc-dc power converter \\
\hline$S_{1}-S_{6}$ & Switches in HERIC inverter \\
\hline$v_{\text {carr }}$ & Carrier signal \\
\hline$v_{d}$ & Direct voltage in $\mathrm{d}-\mathrm{q}$ frame \\
\hline$v_{d}^{*}$ & Direct voltage control signal in $\mathrm{d}-\mathrm{q}$ frame \\
\hline$v_{q}$ & Quadrature voltage in $\mathrm{d}-\mathrm{q}$ frame \\
\hline$v_{q}^{*}$ & Quadrature voltage control signal in $\mathrm{d}-\mathrm{q}$ frame \\
\hline$v_{\sin }$ & Modulation signal \\
\hline$v_{A N}$ & Voltage of A-N terminals of PV modules \\
\hline$v_{B N}$ & Voltage of B-N terminals of PV modules \\
\hline$v_{C M}$ & Common-mode voltage \\
\hline$v_{D M}$ & Differential-mode voltage \\
\hline$v_{P N}$ & Voltage of P-N terminals of PV modules \\
\hline$V_{g}$ & Grid voltage \\
\hline$V_{P V}$ & PV system voltage \\
\hline$V_{\text {ref }}$ & Reference voltage \\
\hline$V_{1}$ & PV output voltage \\
\hline$V_{2}$ & Boost converter output voltage \\
\hline$V_{2}^{*}$ & Reference of boost converter output voltage \\
\hline$\Delta V_{P V}$ & Variation on PV system voltage \\
\hline$\Delta P_{P V}$ & Variation on PV system power \\
\hline$\eta_{E u}$ & European efficiency \\
\hline$\eta_{\text {Con }}$ & Conversion efficiency \\
\hline$\eta_{C a}$ & Californian efficiency \\
\hline
\end{tabular}




\section{References}

[1] Zaid SA, Kassem AM. "Review, analysis and improving the utilization factor of a PV-grid connected system via HERIC transformerless approach". Renewable and Sustainable Energy Reviews, 73, 1061-1069, 2017.

[2] REN21. "Renewables 2017 Global Status Report". Paris France, 2017

[3] Freddy TKS, Rahim NA, Hew WP, Che HS. "Comparison and analysis of single-phase transformerless grid-connected PV inverters". IEEE Transactions on Power Electronics, 29(10), 5358-5369, 2014.

[4] Zhang L, Sun K, Xing Y, Xing M. "H6 transformerless full-bridge PV grid-tied inverters". IEEE Transactions on Power Electronics, 29(3), 1229-1238, 2014.

[5] Li W, Gu Y, Luo H, Cui W, He X, Xia C. "Topology review and derivation methodology of single-phase transformerless photovoltaic inverters for leakage current suppression". IEEE Transactions on Industrial Electronics, 62(7), 4537-4551, 2015.

[6] Yang Y, Blaabjerg F, Wang H. "Low-voltage ride-through of single-phase transformerless photovoltaic inverters". IEEE Transactions on Industry Applications, 50(3), 1942-1952, 2014.

[7] Poliseno MC, Mastromauro RA, Liserre M. "Transformerless photovoltaic (PV) inverters: A critical comparison". 2012 IEEE Energy Conversion Congress and Exposition (ECCE), Raleigh, NC, USA, 15-20 September 2012.

[8] Jedtberg H, Pigazo A, Liserre M, Buticchi G. "Analysis of the robustness of transformerless PV inverter topologies to the choice of power devices". IEEE Transactions on Power Electronics, 32(7), 5248-5257, 2017.

[9] Xiao HF, Zhang L, Li Y. "A zero-voltage-transition HERIC-type transformerless photovoltaic grid-connected inverter". IEEE Transactions on Industrial Electronics, 64(2), 1222-1232, 2017.

[10] Kaouane M, Boukhelifa A, Cheriti A. "Regulated output voltage double switch buck-boost converter for photovoltaic energy application". International Journal of Hydrogen Energy, 41(45), 20847-20857, 2016.

[11] Li S, Attou A, Yang Y, Geng D. "A maximum power point tracking control strategy with variable weather parameters for photovoltaic systems with DC bus". Renewable Energy, 74, 478-488, 2015.

[12] Khosroshahi A, Abapour M, Sabahi M. "Reliability evaluation of conventional and interleaved DC-DC boost converters". IEEE Transactions on Power Electronics, 30(10), 5821-5828, 2015.

[13] Kawa A, Penczek A, Piróg S. "DC-DC boost-flyback converter functioning as input stage for one phase low power grid-connected inverter". Archives of Electrical Engineering, 63(3), 393-407, 2014.
[14] Jung DY, Ji YH, Park SH, Jung YC, Won CY, "Interleaved soft-switching boost converter for photovoltaic power-generation system". IEEE Transactions on Power Electronics, 26(4), 1137-1145, 2011.

[15] Pires VF, Foito D, Baptista FRB, Silva FJ. "A photovoltaic generator system with a DC/DC converter based on an integrated boost-cuk topology". Solar Energy, 136, 2016.

[16] Banaei MR, Ardi H, Alizadeh R, Farakhor A. "Non-isolated multi-input-single-output DC/DC converter for photovoltaic power generation systems". IET Power Electronics, 7(11), 2806-2816, 2014.

[17] Khan MJ, Mathew L. "Different kinds of maximum power point tracking control method for photovoltaic systems: a review". Archives of Computational Methods in Engineering, 24(4), 855-867, 2016.

[18] Xiao W, El Moursi MS, Khan O, Infield D. "Review of grid-tied converter topologies used in photovoltaic systems". IET Renewable Power Generation, 10(10), 1543-1551, 2016.

[19] Xiao W, Ozog N, Dunford WG. "Topology study of photovoltaic interface for maximum power point tracking". IEEE Transactions on Industrial Electronics, 54(3), 1696-1704, 2007.

[20] Mei Y, Hu S, Lin L, Li W, He X, Cao F. "Highly efficient and reliable inverter concept-based transformerless photovoltaic inverters with tri-direction clamping cell for leakage current elimination". IET Power Electronics, 9(8), 1675-1683, 2016.

[21] Xiao HF, Lan K, Zhang L. "A quasi-unipolar SPWM full-bridge transformerless PV grid-connected inverter with constant common-mode voltage". IEEE Transactions on Power Electronics, 30(6), 3122-3132, 2015.

[22] Gu Y, Li W, Zhao Y, Yang B, Li C, He X. "Transformerless inverter with virtual DC bus concept for cost-effective grid-connected PV power systems". IEEE Transactions on Power Electronics, 28(2), 793-805, 2013.

[23] Mertens K. Photovoltaics: Fundamentals, Technology and Practice. West Sussex, United Kingdom, Wiley, 2014.

[24] Islam M, Mekhilef S. "Analysis and comparison of different grid-tied transformerless inverters for PV system". 2015 Saudi Arabia Smart Grid (SASG), Jeddah, Saudi Arabia, 7-9 December 2015.

[25] Xiao H, Xie S, Chen Y, Huang R. "An optimized transformerless photovoltaic grid-connected inverter". IEEE Transactions on Industrial Electronics, 58(5), 1887-1895, 2011.

[26] Luo FL, Ye H. Power Electronics: Advanced Conversion Technologies. $2^{\text {nd }}$ ed. Boca Raton/Florida, USA, CRC Press, 2017.

[27] Sharma U, Singh B, Kumar S. "Intelligent grid interfaced solar water pumping system". IET Renewable Power Generation, 11(5), 614-624, 2017. 